\title{
NFC IMPLEMENTATION TO IMPROVE BUSINESS PROCESS
}

\author{
Marisa Karsen \\ Information Systems Department, School of Information Systems, Binus University \\ Jl. K.H. Syahdan No. 9, Palmerah, Jakarta Barat 11480 \\ marisa_karsen@binus.ac.id
}

\begin{abstract}
Every industry needs IT to improve their business and give faster service to customer. The fast growing of social network (Facebook, Twitter, MySpace, LinkedIn) and Smartphone (Blackberry and iPhone) in Indonesia indicate that Indonesian people are already familiar with high technology and it is the right time to introduce new technology in Indonesia. The problem is, the usage of IT-based system in Indonesia is not optimal. Nowadays, people want to do almost everything faster and more convenient using technology. We know that until now, there are a lot of situations that make people queue or wait to get their need. In this kind of situation, we need something that will change the way to do business, that is in effective and efficient way. NFC (Near Field Communication) is considered suitable as the solution. NFC technology as one of payment systems can increase competitive advantage of the company which implements it and will make it a leader in the industry. This new technology could attract customers, especially Indonesian people in big cities who want to do their transaction in quick and efficient way. NFC is already implemented in Korea and USA as substitution of e-wallet that can help people to make transactions easier and faster. I believe NFC can be implemented in Indonesia to make new trend of doing business.
\end{abstract}

Keywords: new technology, business, payment system, NFC (Near Field Communication)

\begin{abstract}
ABSTRAK
Setiap industri membutuhkan TI untuk meningkatkan bisnis mereka dan memberikan layanan yang lebih cepat kepada pelanggan. Pesatnya perkembangan jejaring sosial (Facebook, Twitter, MySpace, LinkedIn) dan Smartphone (Blackberry dan iPhone) di Indonesia menunjukkan bahwa masyarakat Indonesia sudah akrab dengan teknologi tinggi dan ini adalah waktu yang tepat untuk memperkenalkan teknologi baru di Indonesia. Masalahnya adalah, penggunaan sistem berbasis TI di Indonesia belum optimal. Saat ini, orang ingin melakukan segala sesuatu lebih cepat dan lebih nyaman menggunakan teknologi. Kita tahu bahwa sampai saat ini, ada banyak situasi yang membuat orang mengantri atau menunggu untuk mendapatkan kebutuhan mereka. Dalam situasi seperti ini, kita perlu sesuatu yang dapat mengubah cara untuk melakukan bisnis, yaitu dengan efektif dan efisien. NFC (Near Field Communication) dianggap cocok sebagai solusinya. Teknologi NFC sebagai salah satu sistem pembayaran dapat meningkatkan keunggulan kompetitif perusahaan yang mengimplementasikannya dan akan membuatnya lebih unggul. Teknologi baru ini bisa menarik pelanggan, terutama orang-orang Indonesia di kota-kota besar yang ingin melakukan transaksi dengan cepat dan efisien. NFC sudah diimplementasikan di Korea dan Amerika Serikat sebagai pengganti e-wallet yang dapat membuat transaksi lebih mudah dan lebih cepat. Saya percaya NFC dapat diimplementasikan di Indonesia untuk membuat tren baru dalam berbisnis.
\end{abstract}

Kata kunci: teknologi baru, bisnis, sistem pembayaran, NFC (Near Field Communication) 


\section{INTRODUCTION}

People need technology for doing business. Business needs innovation to create competitive advantage and innovation itself is important, as it does not only influence at the level of the individual enterprise but also increasingly as the well spring for national economic growth (Tidd and Bessant, 2009).

Information Technology is all forms of technology used to create, store, exchange, and use information (Pearson \& Saunders, Strategic Management Information Systems, 2009, p. 16) and has important role in our business. Every company needs IT to run their business and IT has made a significant contribution to economic growth and quality of life. Almost in every industry, transaction might not be done smoothly without IT. Further than that, companies that want to focused in their core business, tend to use IT system provider to help them make IT innovation to attract customer, because IT system provider is expert in IT business. Some companies also buy ready IT program, such as Oracle, SAP, etc.

Nowadays, people are aware and always waiting for new technology. We can see if a new or different technology appears, people are willing to try it. So, if we come out with new idea using new technology, we believe we can penetrate the market. In other countries, such as USA and Korea, there is new technology for doing daily life transaction, which is Near Field Communication (NFC).

Near Field Communication (NFC) is a short range wireless technology compatible with contactless smart cards (ISO/IEC 14443) and radiofrequency identification (RFID). NFC is on the 13.56 $\mathrm{MHz}$ frequency band and operates at a distance of less than $4 \mathrm{~cm}$. It uses magnetic field induction for communication and powering the chip (Muhammad Qasim Saeed, Colin D. Walter, 2012).

NFC harmonizes today's diverse contactless technologies, enabling current and future solutions in areas, such as Access Control, Consumer Electronics, Healthcare, Information Collection and exchange, Loyalty and Coupons, Payments, Transports, Other Possibilities (NFC Forum, 2013).

NFC is a technology that could build communication between your Smartphone and NFC chip without touching the object, such as reader, touch screen, poster, restaurant menu, etc. We see that a lot of in many kind industries (theater, restaurant, bank, amusement park, etc), and we think how to make it efficient. Using NFC technology, people can do transaction in efficient way without queuing in front of the cashier.

There are a lot of NFC vendors abroad. On contrary, Indonesia has not had any yet. This opens big opportunities for many companies to using this technology to give better service to end customers. Once a company gives better service to customers, it will create loyal customers and indirectly will increase profit. The trends of "Technological Supremacy" of mobile phones and smartphones hit Indonesia hard, company in Indonesia use this opportunity by making a rather low cost "Mobile ads" than the traditional marketing. The graphic below shows the details (Figure 1). 


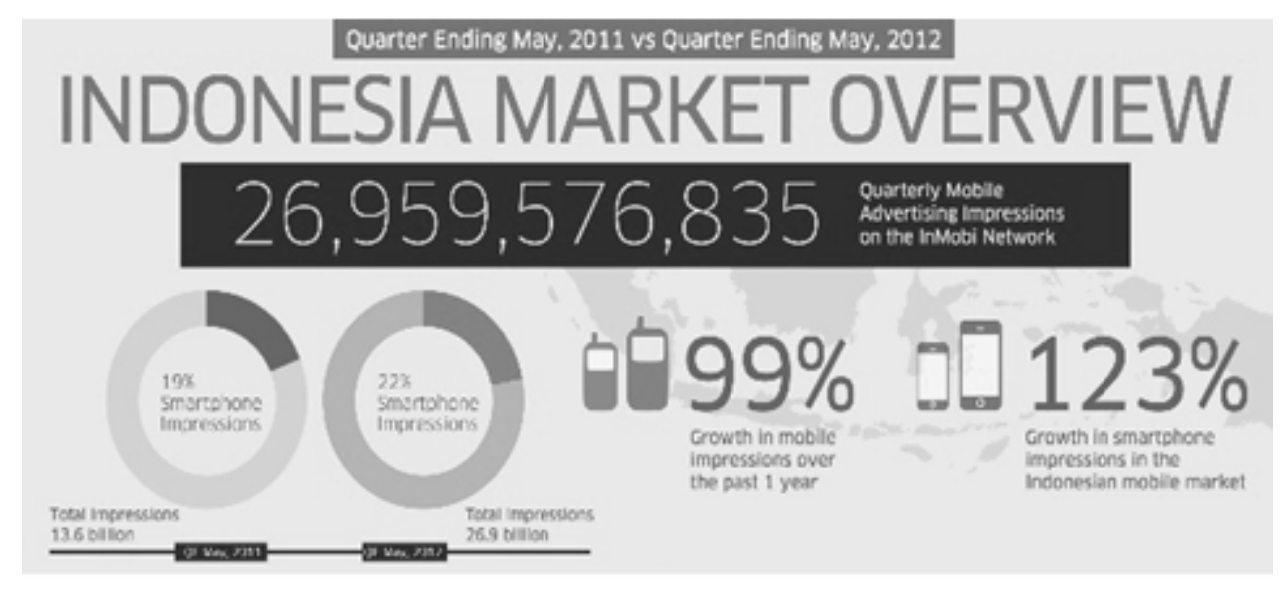

Figure 1 Indonesia Mobile Advertising Prospect in 2012 (www.inmobi.com, 2012)

The main goal presented in this research is to analyze the opportunities about NFC implementation in Indonesia to improve the way of doing business. This paper has the following objectives: (1) to introduce the new way of doing business transaction using NFC technology for the people in Indonesia that want to do business in the most effective and efficient way; (2) to provide some opportunities about NFC implementation in Indonesia. In this paper, we only focus on analyzing the opportunities about NFC implementation in Indonesia to improve the way of doing business and increase customer engagement.

\section{METHOD}

\section{Theoretical Framework}

The first thing to do is studying IT industry in other developed country such as USA and Korea that already implemented NFC technology. It is followed by studying about IT industry development in Indonesia and conducting market research by questionnaire to know about market opinion. Based on the questionnaire, we can analyze the opportunities about NFC implementation in Indonesia (Figure 2).
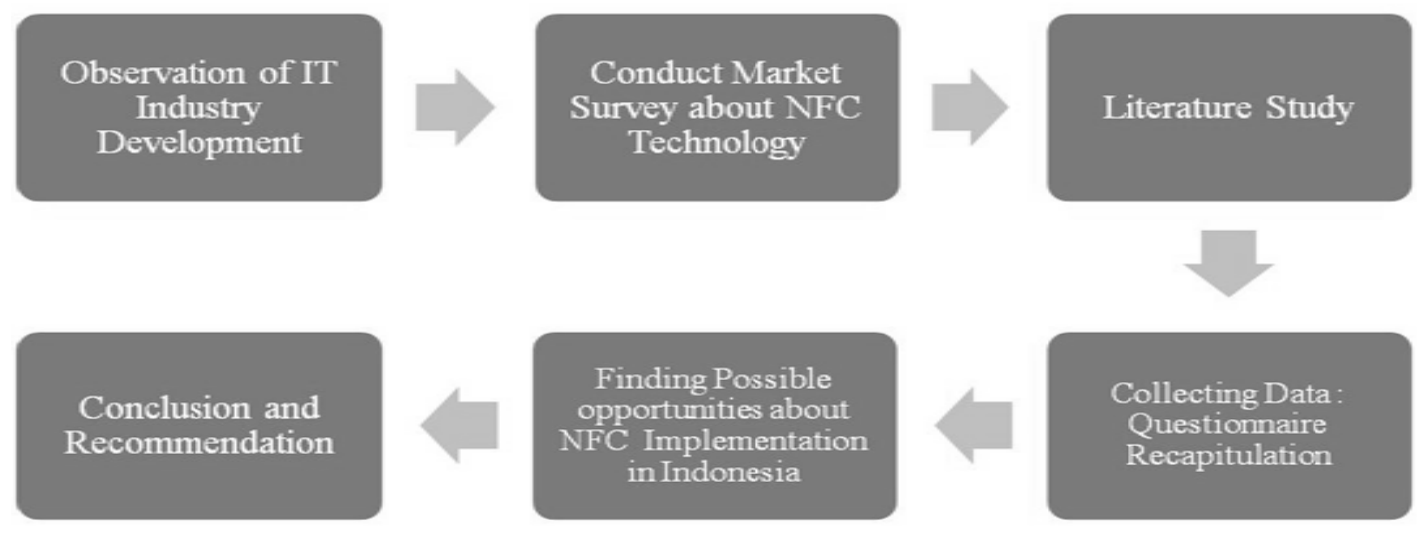

Figure 2 Methodology 


\section{Observation of IT Industry Development}

First step to do this research is observation of IT Industry Development in other country and in Indonesia. In this case, the observation is scoped in any kind of Readers technology that support to doing business, such as barcode, RFID, QR Code, and NFC. Having data collected, I make comparison about the technologies and find that NFC is the best way to help doing business in effective and efficient way (Tabel 1).

Table 1 Comparison Technology of Readers

\begin{tabular}{|c|c|c|c|c|c|}
\hline No & Categories & NFC & Barcode & RFID & QR Code \\
\hline 1 & Mobility & NFC Tag & $\begin{array}{l}\text { Printable } \\
\text { code }\end{array}$ & RFID Tag & Printable code \\
\hline 2 & Transfer Speed & $\begin{array}{c}\text { Fast } \\
\text { Reading (2 } \\
\text { second) }\end{array}$ & $\begin{array}{c}\text { Slow } \\
\text { Reading }\end{array}$ & $\begin{array}{l}\text { Fast Reading } \\
\text { (2-3 second) }\end{array}$ & Slow Reading \\
\hline 3 & Transfer data & Yes & No & No & No \\
\hline 4 & Interaction & Two way & One Way & One Way & One Way \\
\hline 5 & $\begin{array}{l}\text { Security } \\
(1-4) * \text { Low- } \\
\text { High }\end{array}$ & 4 & 1 & 3 & 2 \\
\hline 6 & Reader & $\begin{array}{c}\text { Smartphone } \\
\text { \& Reader } \\
\text { Machine }\end{array}$ & $\begin{array}{c}\text { Smartphone } \\
\text { \& Reader } \\
\text { Machine }\end{array}$ & $\begin{array}{l}\text { Reader } \\
\text { Machine }\end{array}$ & $\begin{array}{l}\text { Reader } \\
\text { Machine }\end{array}$ \\
\hline 7 & Error on read & Low & High & Medium & High \\
\hline 8 & Easiness on use & Easy & Easy & Easy & Medium \\
\hline
\end{tabular}

\section{Conducting Market Survey about NFC Technology}

Finding that NFC is the best way compared to another Readers technology, I conduct market survey by questionnaire to know about people opinion about NFC technology and the possibility to implement NFC technology in Indonesia.

\section{Literature Study}

During the survey, I collect theories about information system and NFC technology to know ideal condition about NFC technology implementation. I obtain the theories from book, internet, and other media which related to the scoped of works.

\section{Collecting Data}

Obtaining responses from 100 respondents about IT development and NFC technology implementation possibility, I make questionnaire recapitulation to know about whole respondents' opinion.

\section{Finding Possible Opportunities about NFC Implementation in Indonesia}

Identifying the respondents' opinion of NFC technology implementation in Indonesia, I try to figure out about possible opportunities about NFC implementation in Indonesia and create Porter Five Forces analysis and business model. 


\section{Conclusion and Recommendation}

Having some analysis about the possibility of NFC implementation in Indonesia, I can make conclusion and recommendation which represent the whole results in the study. The conclusion should give more understanding about the goals and ensure the analysis will make right decision.

\section{RESULTS AND DISCUSSION}

\section{Market Survey of NFC Technology}

We offer questionnaire to 100 respondents and this is the recapitulation (Figure 3):

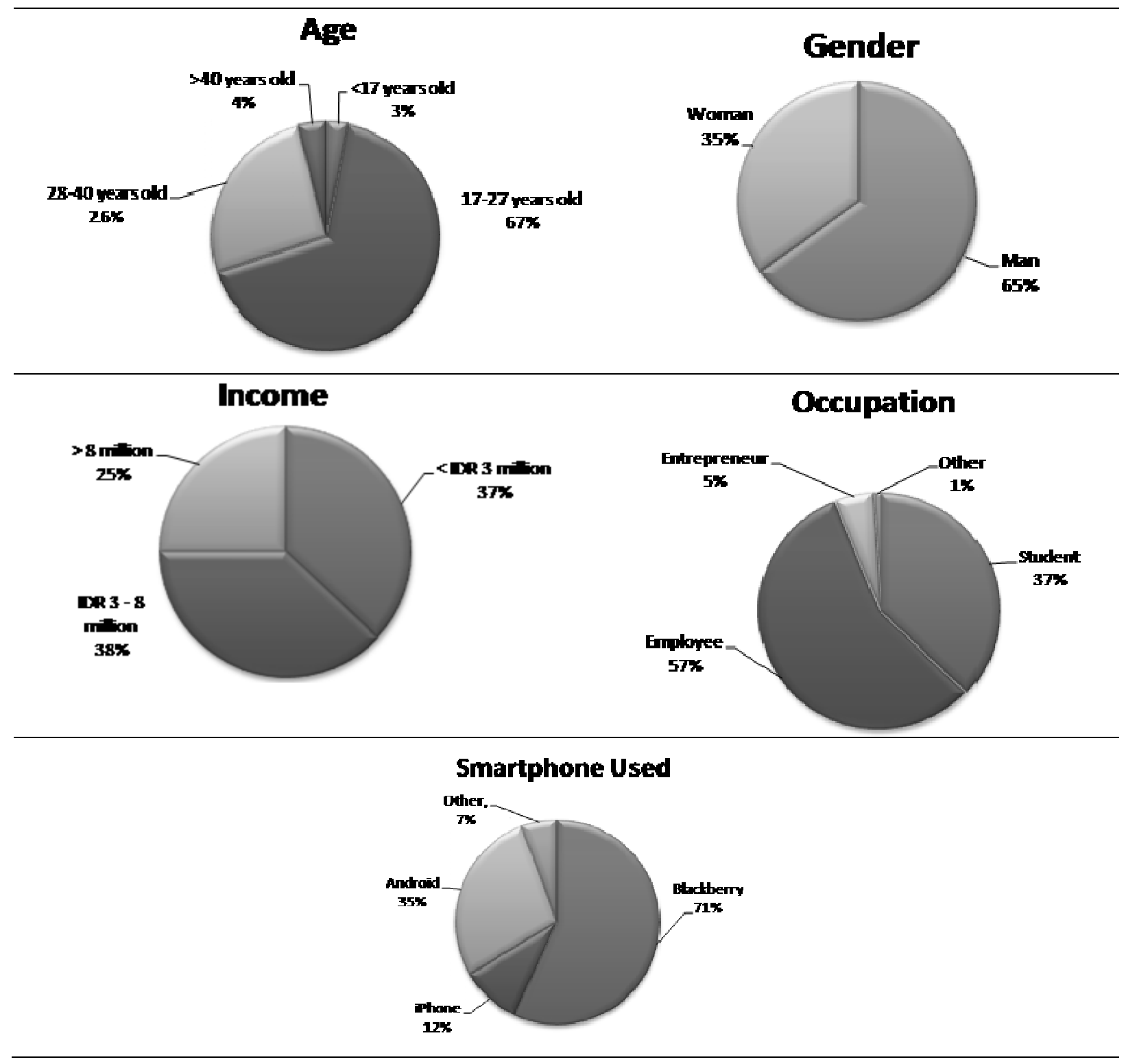

Figure 3 Respondents profile 
As we can see from the respondent data, most of the smartphone users are middle-income customers, which is 3-8 million, while most of the customers are office workers, or employees. The age of the customers mostly is around 17-27 years old (67\%) and 28-40 years old (26\%). Based on this data, we can assume that Smartphone users are mostly young adult people using blackberry as their Smartphone (71\%).

After that, how often people change their Smartphone and what is the main reason to change their Smartphone are described below (Figure 4):

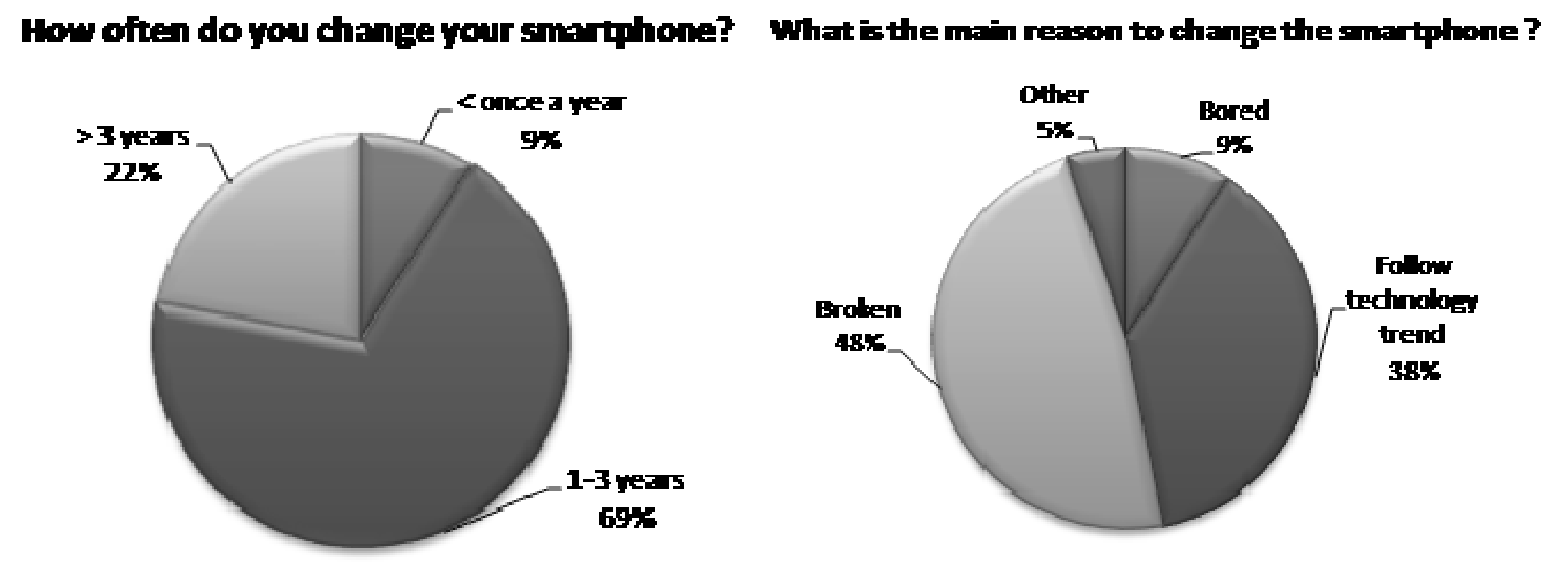

Figure 4 How often people change their smartphone and the main reason

From Figure 4, we can see that $69 \%$ respondents change their Smartphone within $1-3$ years because of broken (48\%) and following (updating) the technology (38\%). This condition means that people would like to change their smartphone with a more durable one. Besides, they also want to be the first to use the new technology, such as NFC technology that embedded in Smartphone.

Next, the use of QR Code is described as follows (Figure 5). This question is only for blackberry user s(71\% of the whole respondents).

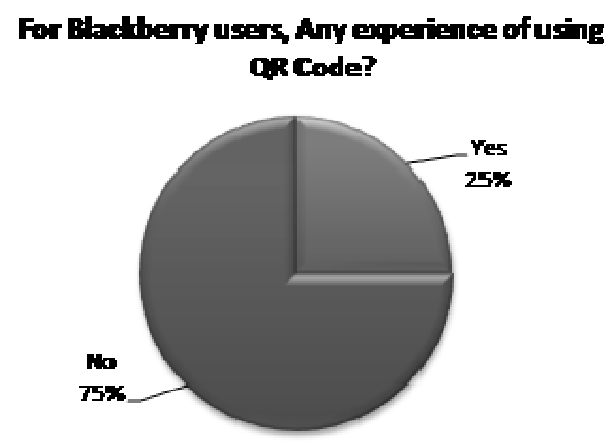

Figure 5 Experience in using QR code for Blackberry users

Based on Figure 5, only 25\% have had experience in using QR Code, while 75\% have not had. It means that people still find some difficulties in using QR Code, such as in downloading applications and scanning QR code picture on the merchant that actually takes time. It also takes more time to do the transaction or even only go to the merchant website (three-minute loading). We need something that can be faster than QR Code to do transactions. 
When asked whether the respondents have had any transaction through their smartphone, 38\% have already done transactions through their Smartphone with long time frequency while $62 \%$ have not had any (Figure 6). This condition means that people still find difficulties to do transaction through their smartphone, with several steps that takes time (login, select, pay, confirmation, token input, etc). We also get information about the transactions done by respondents. They are local application for buy phone balance, electricity balance, fund transfer and credit card payment using mobile banking.

\section{Any eqperience to do transaction through your smarthone?}

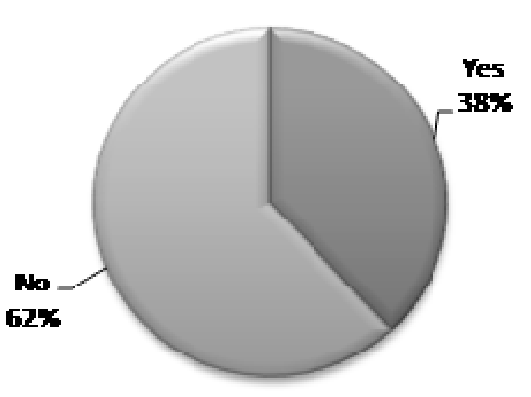

If Yes, How manytimes

that you do the transaction?

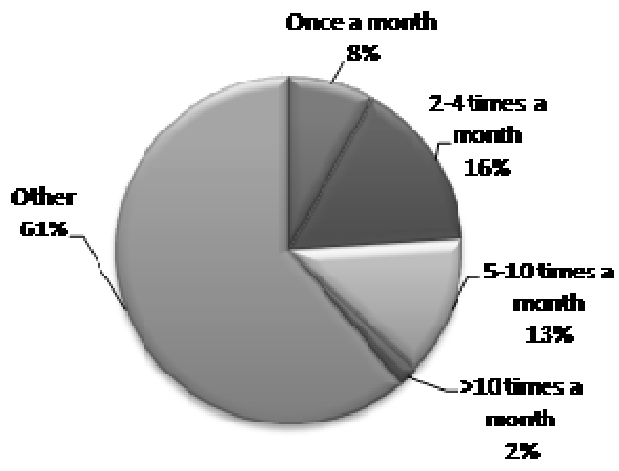

Figure 6 Experiences of doing transaction via smartphone

Now let's find out more about NFC technology from respondents' perspective. Based on Figure 7, we can see that the slack between the respondents who already heard about NFC technology (55\%) with the respondents who didn't heard about NFC technology (45\%) is only $10 \%$. Also from $45 \%$ respondents, most of them already know that NFC is an integration system and can capture data. This condition means many people in Indonesia, especially big city like Jakarta like to follow technology and it is possible to implement NFC technology in Indonesia, which is started in Jakarta.

What are you thinking about NFC?
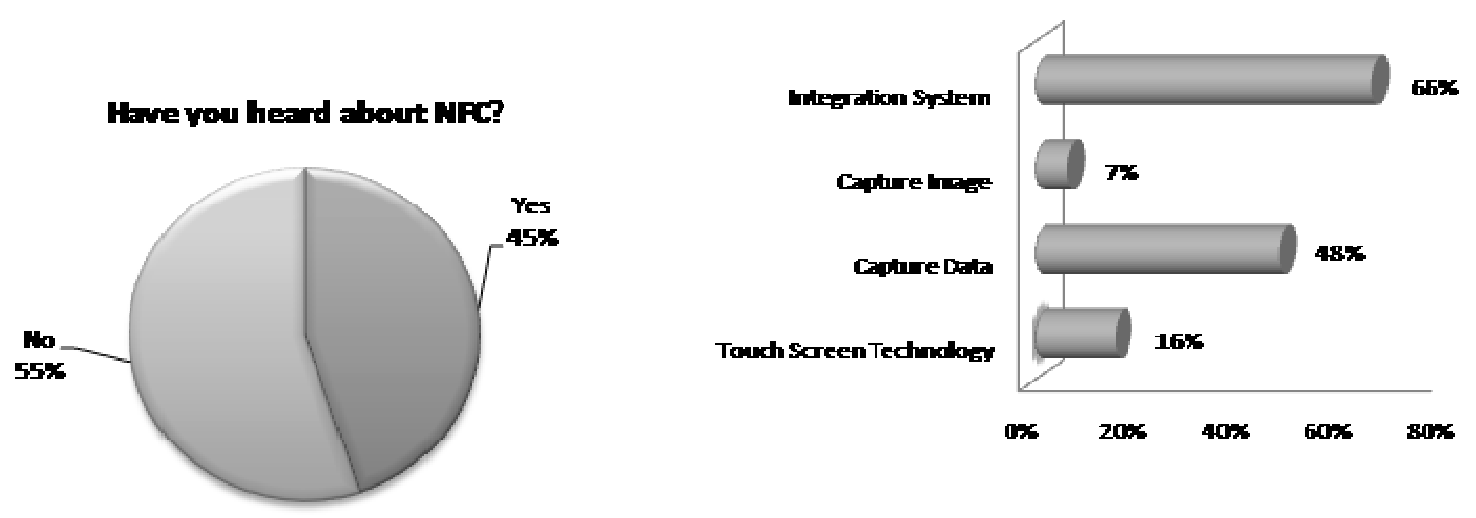

Figure 7 Respondents opinion about NFC technology

89\% of respondents think that NFC technology should be implemented in Indonesia because it can improve business efficiency (Figure 8). 69\% would like to change their smartphone with one that installs NFC on it. This condition means there are a lot of opportunities to implement NFC technology in Indonesia. I believe it will be successful in the market, because a large number of people are willing to try and use this technology. 


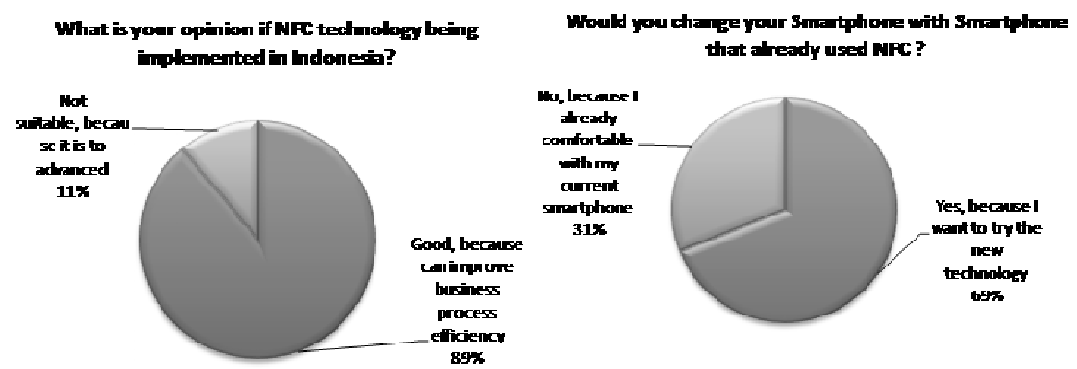

Figure 8 Respondents opinion about NFC implementation in Indonesia

\section{TOWS Analysis}

To analyze deeper, I make TOWS analysis which is analyze from external to internal. TOWS Analysis is a variant of the classic business tool, SWOT Analysis. TOWS and SWOT are acronyms for different arrangements of the words Strengths, Weaknesses, Opportunities and Threats. The TOWS matrix illustrates how the external opportunities and threats facing a particular corporation can be matched with the company`s internal strengths and weaknesses to result in four sets of possible strategic alternatices (Thomas L.Whellen, David J. Hunger, 2008).

\section{Threats}

We know that technology is growing so fast. When one company implements NFC technology, it will create more competitors that offer the same or better technology.

\section{Opportunities}

Less competitor - of course if a company implement NFC technology as new business model, The company will became a pioneer of NFC technology implemented in Indonesia, but the company must makes strategies to sustain in the market. Create New Market - the new technology will create new market segment that is people who aware in technology and need efficiency in doing their business or daily transaction. High technology awareness - we know that people, especially young generation, are happy to use new technology and always wait for innovation. This is a good opportunity to bring this new technology to Indonesia.

\section{Weaknesses}

NFC is a new technology. The implementation of NFC costs an expensive budget. Indonesia has not had NFC providers yet, so we still need foreign investor to support in terms of investment. Additionally, the investors do not know whether the market will accept or not; it still has a chance to be rejected.

\section{Strengths}

(1) Innovation in IT and business process make more efficiency for end customers and merchants.

(2) NFC can be implemented in any kind of industries because the system is general and can be customized based on corporate customers needs.

(3) This new business model will surely create Blue Ocean Strategies, because it is new technology which creates new market segment. 


\section{Possibility of NFC Implementation}

NFC devices can be used in conjunction with image display devices like digital photo frames for displaying images very quickly. All user needs to do is touching the photo frame with the image ready to be sent. Then the connection is established and the image is sent over Bluetooth. NFC is backward compatible with RFID. Therefore it is perfectly feasible to use an NFC enabled device as an RFID key. This can be used with traditional RFID access control systems as a replacement for the key fobs and cards currently used. Wireless car keys using NFC are being developed by BMW with personalized settings stored into each key. They have developed an NFC car key system which will link into the current navigation system of the car which already allows for hotel reservation, and train ticket booking. Tickets and reservations can now be stored on the NFC card which can then in turn be used to gain access to the hotel room or to validate the ticket with the conductor. Then applications for Smartphone will start to appear that allow the user to create their own NFC tags. One application developed and being distributed for free is NXP Tag Writer for the Android Smartphone. It enables phone to send a signal to write contact details, URLs and SMS messages onto an NFC enabled tag which can be on items like business cards up to posters. NFC has a shorter range than RFID. It gives a more security features, because there won`t be no unauthorized communication takes place. Another advantage is the low power consumption and security concers such as bluetooth, and also works without power source, using the help of NFC Tag. Figure 9 below show the general usage of it (Curran,et al, 2012).

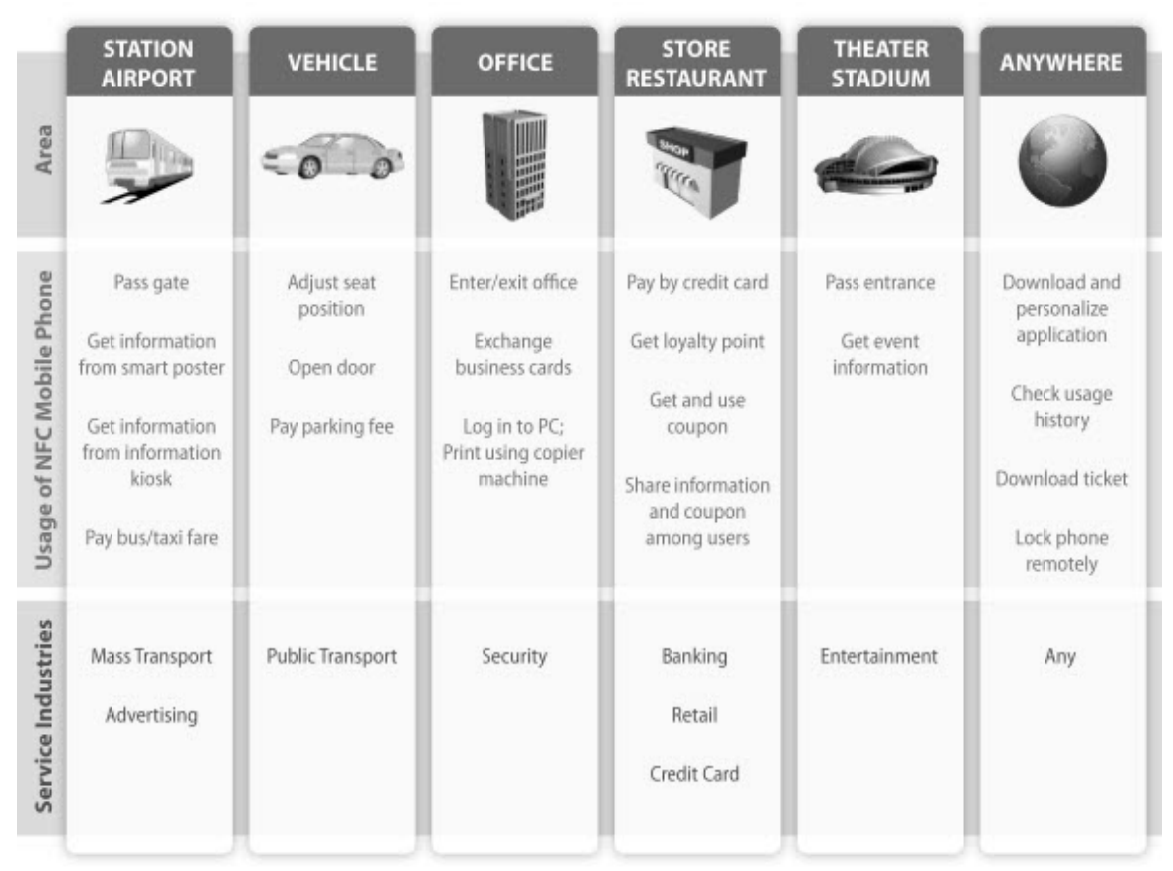

Figure 9Potential NFC technology usage (Curran,et al, 2012)

\section{Business Process using NFC}

NFC technology can be used by simply tapping user's smartphone at NFC reader placed by system provider at a Merchant. After that, the NFC tag will send signal to Merchant's server that will confirm payment option. After making payment, the system will send signal to end users' Smartphone about order and payment confirmation. This is the example about user interface of NFC on end users' smartphone (Figure 10). 

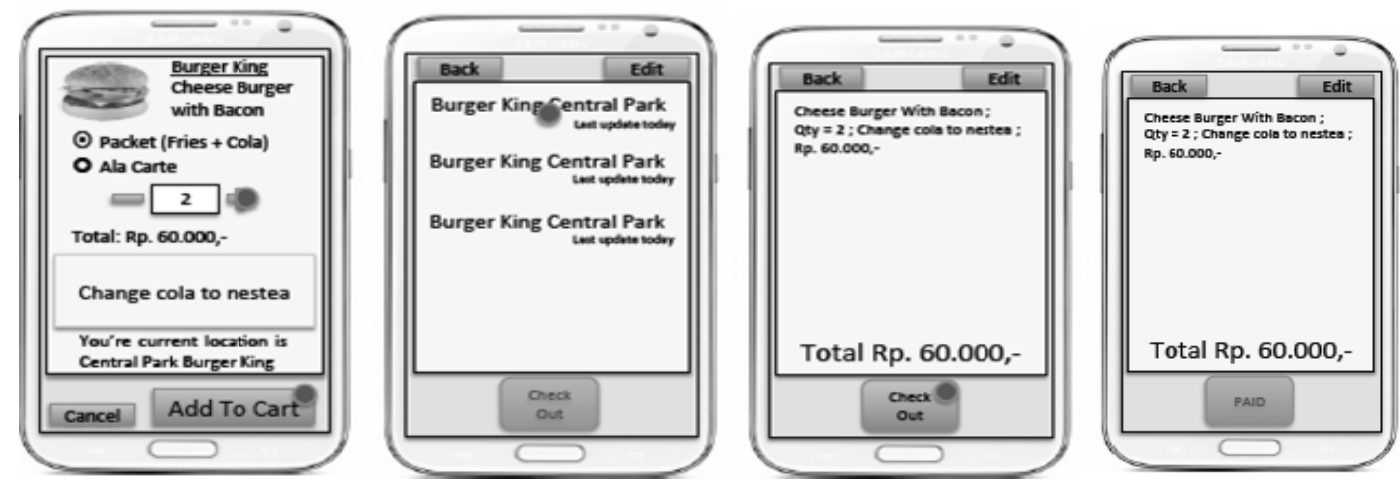

Figure 10.NFC Transaction methods

A company that will implement NFC technology in Indonesia needs System Provider that provides services to Merchants. It could make installation and maintenance about NFC system. It also has cooperation with bank.

Here is the example of payment mechanism using myWallet with top up via internet banking between customers, bank, and system provider (Figure 11). When end customers want to top-up via ebanking, the system will request to input e-banking user ID. After that, end customers must open ebanking website and verify e-banking user ID in 1x24 hour. Then the system will send transaction confirmation. If end customers agree, the bank system will create direct debit from end customers' account and send debit notification to end customers. After that, system provider will receive top-up amount notification and receive the top-up money after end-of-day settlement (it means $\mathrm{D}+1$ on working day).

\section{Benefit of NFC Implementation}

Benefit for end-users are: (1) ease of use - this is the most obvious to use, as it simplify systems, from complex to a more daily task. NFC will let user to not carry multiple cards, or their office identification, or even member cards of their store department; (2) security - some people think that storing information all in one place on your smartphone may be dangerous. On contrary, NFC provides a safer environment than your physical wallet. If your wallet is stolen, a thief has instant access to all your credit cards, debit cards, and photo Ids. NFC uses password to protect your transaction. It is safer also because you can have a pasaword to protect your smartphone usage. In addition, NFC creates a secure channel for communication and uses data encryption when sending sensitive information between your phone and othe device, such as card reader (Wozniaki, 2013); (3) prestige - prestiges is one of the top option for people to buying things. In Indonesia NFC technology was still relatively unknown The first users will have the "privilages" to brag to their friends; (4) additional payment method - With its level of security, NFC technology is used as a additional payment method for people that don't want to bring their credit card, debit card, or cash. This payment, though people thinked it was unsecure, is supposedly a secure services; (5) value added system - NFC potential uses is really big which may affect people`s way to do their business or daily life. Additionally, there is no need to change user's smartphone since it works with all platforms.

Meanwhile, the benefits for merchants are: (1) human resources allocation -the implementation of NFC technology will simplify workflow, so that corporate might be able to allocate their worker into other workforce. The most obvious implementation is in the movie theater. As the movie ticket data is stored in visitor's smartphone, and is checked using a computer database, ushers who check tickets could be allocated elsewhere; (2) value added system, such as decreasing queue; (3) more understanding on customers' behaviour - the data of consumer behaviour could be collected and 
analyized for further company usage.This condition will increase customer engagement because the Merchant actually know the customers' behavior; (4) changing mindset - end users will consider the corporate users innovative. It will gain prestiges; (5) faster additional transaction method -the transaction system using NFC will serve as an additional payment services, with the advantages of faster transaction than common debit or credit cards do.

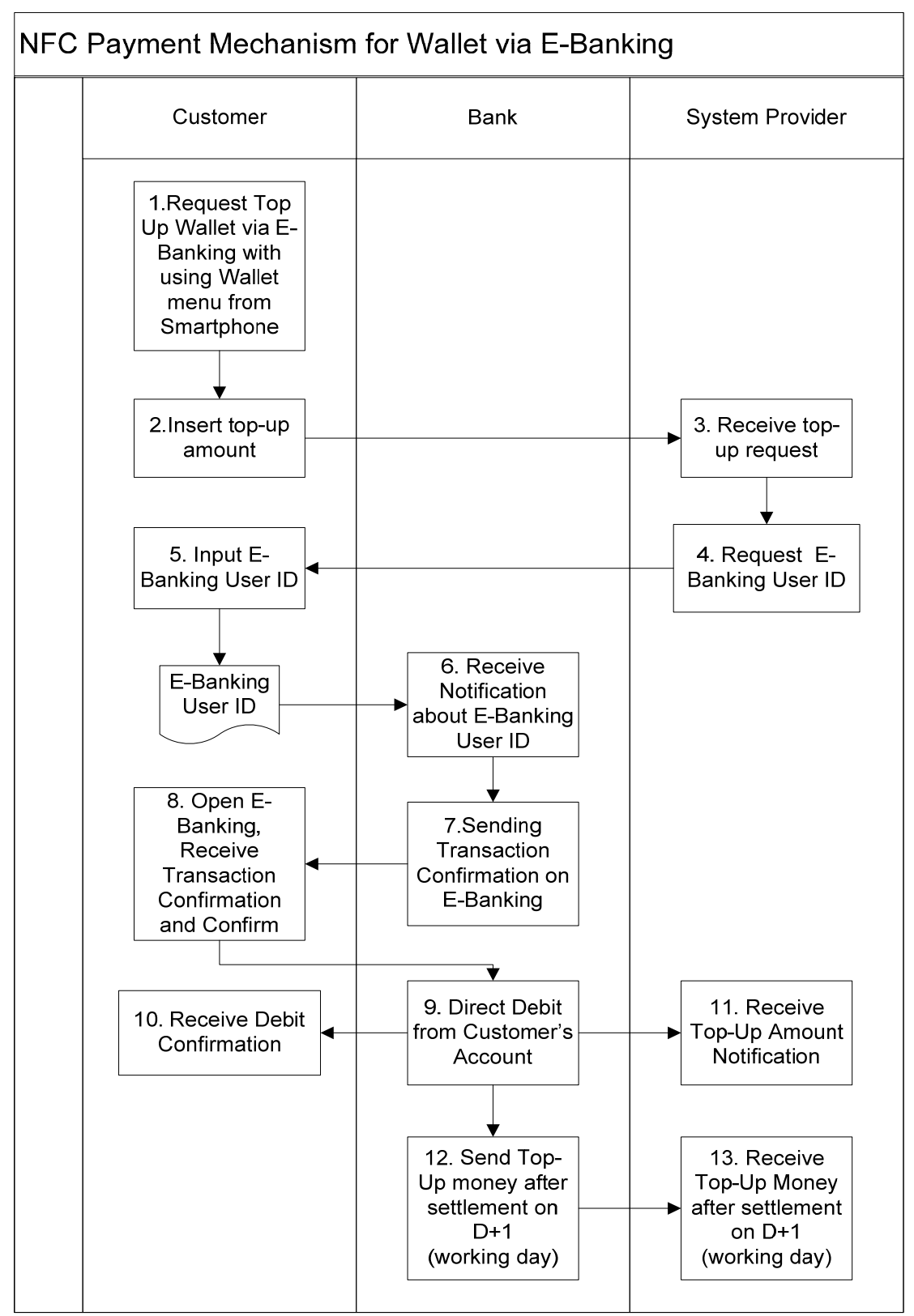

Figure 11 NFC payment mechanism using MyWallet

\section{CONCLUSION}

From the discussion about NFC implementation in Indonesia above, it can be concluded that NFC technology is suitable to be implemented in Indonesia. It will support business processes in effective and efficient way to provide excellent service to merchants and end users. Actually, I am 
really confident and have indefinite trust that NFC technology implementation in Indonesia will be possible with condition that there is a system provider. We can start with NFC implementation for transactions first, but in the future, I recommend to implement NFC in many areas, such as transportation, advertising, office and entertainment. During technology development in Indonesia, we believe that NFC technology is feasible to be implemented because according to our market survey, most of Indonesian people, especially people of Jakarta kindly follow technology. Further, mostly Smartphone launched in 2011, such as Blackberry, Android, and Windows are already embedded with NFC inside (Computer World, 2012). This condition makes more possibility to implement this kind of business model in Indonesia.

\section{REFERENCES}

Computer World. (2012). Despite Apple, NFC is Catching on -- Just Not for Payments Quite Yet. Accessed from ComputerWorld Web Site: http://www.computerworld.com/s/article/9234736/Despite_Apple_NFC_is_catching_on_just_ not_for_payments_quite_yet।

Curran, K., Millar, A. and McGarvey, C. (2012, April 24). Near Field Communication. International Journal of Electrical and Computer Engineering (IJECE), 372.

NFC Forum. (2013). About NFC. Accessed from http://www.nfc-forum.org/aboutnfc/.

Pearson, K. E., \& Saunders, C. S. (2009). Strategic Management Information Systems. Florida: John Willey \& Sons, Inc.

Saeed, Muhammad Qasim and Walter, Colin D. (2012, March/June). An attack on Signed NFC Records and Some necessary revisions of NFC Specifications. International Journal for Information Security Research (IJISR), 2 (1), 325.

Tidd, Joe and Bessant, John (2009). Managing Innovation: Integrating Technological, Market and Organicational Change. Chicester: John Wiley \& Sons.

Whellen, Thomas L.and Hunger ,David J. (2008). Strategic Management and Business Policy: Eleventh Edition. Upper Saddle River: Pearson.

Wozniaki, M. T. (2013). Benefits of Near Field Communication. Accessed from http://www.nearfieldcommunicationnfc.net/benefits.html. 